Gramáticas de la (¿post?) violencia:

identidades, guerras, cuerpos y fronteras

\title{
The Guarani Farm: indigenous narratives about removal, reclusion and escapes during the military dictatorship in Brazil
}

\section{Celeste Ciccarone}

' Universidade Federal do Espírito Santo, Centro de Ciências Humanas e Naturais, Departamento de Ciências Sociais, Vitória/ES, Brasil

\begin{abstract}
This article presents some of the results of a critical exercise concerning the multiple uses of the past, considering the relations between indigenous peoples, state power structures and sectors of regional society. It reveals how the complex interplay between the construction of a regional mythography and the notion of "demographic voids" (Moreira, 200o) was created at the expense of the forced removal and reclusion of Guarani and Tupinikim groups and the expropriation of their lands in Espírito Santo state, Brazil. The study focuses on the indigenous versions of historical situations, the multiple forms of relationship between the state and indigenous peoples and the conditions of production of ethnographic data (Oliveira Filho, 1999:9).
\end{abstract}

Keywords: Military Dictatorship; Indigenous Lands; Guarani Farm; Guarani and Tupinikim Narratives. 


\section{Fazenda Guarani: narrativas indígenas sobre remoção, reclusão e fugas no período da ditadura militar no Brasil}

\section{Resumo}

O artigo apresenta resultados parciais de um exercício crítico sobre os múltiplos usos do passado, no âmbito das relações entre povos indígenas, estruturas de poder estatizadas e segmentos da sociedade regional. Desvenda como o complexo jogo entre a construção da mitografia regional e os "vazios demográficos" (Moreira, 2000) foi criado ao preço da remoção forçada e reclusão de grupos guarani e tupinikim e da expropriação de suas terras no Espírito Santo (Brasil). A pesquisa está direcionada para as versões indígenas de situações históricas, as múltiplas formas de relacionamento entre o Estado e os povos indígenas e as condições de produção dos dados etnográficos (Oliveira Filho, 1999: 9).

Palavras-chave: Ditadura militar; Terras Indígenas; Fazenda Guarani; Narrativas Guarani e Tupinikim. 


\title{
The Guarani Farm: indigenous narratives about removal, reclusion and escapes during the military dictatorship in Brazil
}

\author{
Celeste Ciccarone
}

\section{Introduction}

This preliminary study was conducted after an invitation to participate in the collaborative national research project "Indigenous peoples and the military dictatorship: support for the National Truth Commission (CNV) 1946-1988". The Truth Commission was established in 2011 by Law 12.528 (cf. Relatório Parcial, 2012) and in 2012 a working group was formed to investigate "human rights violations, committed for political purposes and related to land struggles or against indigenous peoples" (Resolution $\mathrm{n}^{\circ} 5 / 2012$ ). Using a wide network of investigations, the collection and analysis of testimonies, written and audiovisual documental sources and the production of regional and at times interconnecting historiographies of differing scales, the process acquired political relevance by constructing a public memory of violations of indigenous rights.

The inclusion of indigenous peoples in the transitional process underway in Brazil to seek justice (despite the limitations in this process), ${ }^{1}$ the reparation of violated individual and collective rights; ${ }^{2}$ and the continuation of investigations of situations that have not been clarified, are indispensable for recognizing and addressing the constant and growing demands of indigenous collectives. These demands have been silenced by the national state in different moments of the country's redemocratization and strengthened by the investigative opportunities and release of previously confidential documents made possible by the working group of the Truth Commission and by the collaborative research.

While the majority of investigations of violent actions by the military regime highlighted the exposure of crimes committed in urban contexts, considering the limits of investigative interests and of the subjects who were the targets of violence, little has been documented about the violence suffered by indigenous peoples during the dictatorship.3 A strong need existed to decolonize and trigger the plurality of memories of suffering and resistance. The rewriting of a hegemonic history, characterized by mute, dead, absent and intermittent Indians, was urgently required, which would focus on the protagonist role of indigenous narratives, and recognize their non-linear constructions of the work of memory; in an authorship densely woven by intersections, variations and suspensions through traumatic trajectories enclosed in silence. To face the absences provoked by the politics of terror of the state of exception, it was necessary to recall, "The right to remember doesn't figure among the human rights consecrated by the UN, but today more than ever it's necessary to reinvigorate it and put it in practice: not to repeat the past, but to avoid repeating it" (Galeano, 1999: 216).

\footnotetext{
1 Such as the lack of recognition that ethnicity is inseparable from human rights violations against indigenous peoples (Calheiros, 2015:4).

2 E. Cofacci de Lima and Rafael Pacheco (2017:237-238) stress the recommendation of the Truth Commission to alter the regime of political amnesty to allow just reparations that consider the damages caused to indigenous groups by the violence of the regime and its effects.

3 On this topic, see: CTI, 2014; Comissão Estadual de Direito à Verdade, à Memória e à Justiça do Amazonas (2015); Revista Aracé, 2017.
} 
With the establishment of the working group for the Truth Commission, the explosion of denouncements in the media focused mainly on the terrorizing practices of physical elimination and torture, ${ }^{4}$ with less emphasis on other forms of violence that had yet to be registered and recognized as practices of ethnic extermination. If the memory of the military regime needed to be reexamined by considering the rise of multiple actors and situations, other memories were painfully revived by indigenous peoples. In their narratives: faces of violence emerged, in addition to the territorial usurpation and devastation, the deceit, persecution and forced removal, the reclusion, slave labor and abandonment. Confronting the invisibility of aggressive and abusive practices, the concealment of crimes and systematic violation of indigenous rights during the dictatorship is a necessary element of making a commitment to their recognition, justice and reparation. It is part of a constant political struggle against the legacy of impunity and collective anesthesia that returned to unsettle Brazil in another violent assault of ethnocide (Viveiros de Castro, 2017).

Since my PhD studies, 5 I have had the opportunity to collect accounts from a group of Guarani Mbya who during the military regime, and along with a Tupinikim ${ }^{6}$ family, had been forcibly removed from their lands in the municipality of Aracruz, in the northern coast of Espírito Santo, which were allocated to agroindustry. These people were confined for six years in a penal colony known as the Fazenda Guarani (the Guarani Farm),7 an institution created to "reeducate" imprisoned Indians - who had been sent there for a period of recovery or a period of reeducation, and labeled as delinquents, degenerates or criminals (Corrêa, 2003: 130). Indians were sent to the Guarani Farm from different areas of Brazil and, most had been involved in land conflicts triggered by the colonization on their lands.

The accounts continued to accompany me on my periodic field trips, haunting a promise that they would be revived, to continue the work of registering the countless terrifying and traumatic situations of violence against indigenous peoples. The narratives focus on their endless resistance struggles against the characterization by the state and the media of traditional indigenous territories as "demographic voids" (Moreira, 2000) - used to feed the hegemonic regional mythography. The Guarani Mbya and Tupinikim held at the Guarani Farm had accepted to revisit their memories of removal, detention and struggle ${ }^{8}$ and, during the conversations, on several occasions expressed a desire to tell even more stories. Although they had seemed destined to be forgotten, the accounts began to flow in a field of utterances and listenings that became increasingly broader, participating in the recomposition of a collective memory and of an other historiography.

\footnotetext{
4 Examples of media coverage: PASSOS, N. Houve extermínio sistemático de aldeias indígenas na ditadura. Carta Maior, o8 Feb.2012; CAMPOS, A. Denúncias apontam o Reformatório Agrícola Krenak, em Minas Gerais, como centro de tortura de índios durante regime militar. Brasil de Fato 10 Sep. 2012; BALZA, G. Comissão da Verdade apura mortes de índios que podem quintuplicar vítimas da ditadura. https://noticias.uol.com.br/politica/ultimasnoticias/2012/11/12/comissao-da-verdade-apura-mortes-de-indios-que-podem-quintuplicar-vitimas-da-ditadura.htm. Accessed in November, 2017.

5 Besides research in press archives, I have collected microfilm from the National Indian Foundation's (FUNAI) internal correspondence found at the Museu do Índia (in Rio de Janeiro), which related to the Guarani Mbya migratory group that reached Espírito Santo lands during the 196os and whose surviving members are the interlocutors referred to in this article

6 Tupinikim is the spelling used by the indigenous people itself, while Tupiniquim is the most common spelling found in non-indigenous documents consulted.

7 The naming was justified, according to a news report from the time: "as an homage to the realization of many dreams and hopes of the remaining Guarani. Therefore, the time of uncertain walks, ended, replaced by the present they desired most: fertile and healthy lands, ready for hunting and fishing, to distance them from the whites and make them, therefore, their own bosses" In: Revista Espírito Santo Agora, set. 1973.

8 The gathering of narratives was conducted among the Guarani Mbya of the villages of Boa Esperança, Três Palmeiras and Piraquê Açu, and the Tupinikim from Caieiras Velhas and Irajá, located in the Caieiras Velhas and Caieiras Velhas II Indigenous Lands, in the municipality of Aracruz (ES). The work included the participation of the Guarani teacher Sandra Benites, master in anthropology (MN/UFRJ), and Ana Paula Gonçalves, who has a bachelor's degree in the social sciences (UFES) and is a master's student in Anthropology (FFLCH/USP), who transcribed the accounts.
} 
However, few non-indigenous interlocutors were willing to collaborate, including researchers. Requests for information were blocked by silence, attitudes of distrust and evasion, or even explicit refusal, which aroused the suspicion that examination of this theme continues to be taboo. ${ }^{9}$

\section{Antecdent}

To map the context in which the violent practices against the Guarani Mbya and the Tupinikim, who had been owners of land along Espírito Santo's north coast, it is necessary to understand a bit of the regional mythography about the indigenous and about the action of the state governors who were indirectly elected during the military regime.

Coffee production gave Espírito Santo worldwide projection, stimulating the policy for demographic whitening, which since the early twentieth century encouraged immigration of Europeans to whom lands were granted that were considered to be "demographic voids" (Moreira, 200o). These lands were gradually cleared of their legitimate inhabitants, who were indigenous peoples, quilombolas [collectives of African descent] and other traditional communities.

The official narrative claim that "there were no Indians in Espirito Santo" was corroborated by the Indian Protection Service (SPI), which had not recognized the presence of Tupikinim in its area of operation, ${ }^{10}$ because they were considered, according to categories in force at the time, "remnants in promiscuous coexistence" with the regional population. The SPI would produce other "demographic voids" in collusion with government and settlers. This involved the removal of the Krenak, Pataxó and Maxacali, who were forcibly removed from their lands, together with a Guarani Mbya group that was intercepted as it was walking to the Pancas Indian Attraction Post, in northern Espírito Santo (Ciccarone, 2001: 253)." The Indigenous Protection Service was thus involved in the decimation of the indigenous population, resulting in over 200 deaths.

The official version presented by the indigenist agency attributed the annihilation to devastating outbreaks of malaria, which led to the extinction of the Pancas Attraction Post in 1937 and SPI's withdrawal from the state. This version is challenged by Antônio Carvalho Vera Kwaray, chief of the Guarani village Boa Esperança (ES) who since childhood had heard stories about "the great killings at Pancas" (Ciccarone, 2001: 254). The fertile land in Espírito Santo's northwest under SPI jurisdiction were target of an intense colonization process. With the collusion of government agents, the extermination of Indians assured the appropriation of the "free" areas. ${ }^{12}$ In the wake of these processes, during the 1940s, the state company for the production of vegetal charcoal (COFAVI) was established in the territory of the Tupinikim. In the mid twentieth century, local researchers (Ruschi, 1954; Pacheco, 1955) had already challenged the government's official narrative that "there were no Indians in Espirito Santo".

While Governor Christiano Dias Lopes (1967-1971) planned the modernization of the state via industrialization, as a response to the collapse of coffee cultivation - which was a persistent idea in the hegemonic regional historiography (Daré, 2010) - a group of Guarani Mbya in a migratory process, guided by shaman Maria Candelária Tatatki Ywa Rete, once again reached Espírito Santo in the 1960s. They settled in Caieiras Velhas, a Tupinikim village on the north coast of the municipality of Aracruz.

\footnotetext{
9 Term used by Prof. Dr. John Monteiro (UNICAMP) in a personal conversation during the research.

10 The main area of operation of the SPI since the beginning of the zoth century extends from southern Bahia, to the Rio Doce region in Minas Gerais, and the north of Espírito Santo, due to the construction of the Bahia-Minas and Vitória-Minas railroads (Paraíso, 1992:420).

11 The Attraction Posts were created as initiatives of the Indigenous Protection Service to confine and integrate the indigenous peoples in regions of recent colonization. The Attraction Post at Pancas was created in 1913 and terminated in 1937.

12 The tragedy of Pancas was the subject of the documentary Genocidio guarani (2013), a collaborative work between chief Antonio Carvalho and the journalist and photographer Rogério Medeiros.
} 
Along their walks (oguata) by the sea through their wide territory, ${ }^{13}$ small family groups took turns in the search for their ancestors' lands. Those lands were revealed in dreams of the shaman leaders and were located in regions of the Atlantic forest that met the requirements for the creation of villages (tekoa) and the exercise of their way of life (Ladeira, 2001; 2007[1992]). The coexistence with the Tupinikim was characterized by a strengthening of political alliances and the avoidance of tensions, as the group occupied a separate space in the community.

Since 1967, the intervention of the National Indian Foundation (FUNAI), the indigenist agency that had replaced the Indian Protection Service (SPI) - which had been riddled by accusations of corruption and violence against Indians - involved collusion with the interests of the colonization projects through omission and a posteriori interventions in indigenous territories. FUNAI maintained the SPI practices of "pacification" and forced removal, conducted in partnership with the military police and other armed forces of the regime. Of all the districts of FUNAI operations, the Ajudância Minas-Bahia (AJMB), under the command of state Military Police Captain Manoel dos Santos Pinheiro from 1969 to 1972, was the scene of some of the period's greatest terror and violence against Indians. Much of the actions were executed in the realm of the notorious "reeducational" institution known as the Reformatório Krenak [Krenak Reformatory] (1969-1972). The Guarda Rural Indígena GRIN [Indigenous Rural Guard] (1969-1979), a militia formed by Indians removed from several regions of Brazil, participated in the actions. The Indians recruited for the militia were forbidden to speak their native languages, reduced to obedient bodies, and trained to commit violence against other Indians, capturing, torturing and disciplining fugitives from the reformatory.

- Are you Indians?

- Yes, we are Indians.

- Where are you from?

- We are from Espírito Santo.

- Do you have a village in Espirito Santo? How is this land of yours?

- There is forest and the company is breaking everything, ruining everything.

- My God, this can't be so. You can't stay here, pack your things, there is a place for you to stay

(Nilson Joaquim da Silva, 2013).

Since the Guarani had arrived at the Caieiras Velhas village, Nilson Joaquim da Silva, a Tupinikim, had joined the Guarani as they moved about to sell their crafts. He was 13 years old when the group was approached by military policemen, in Belo Horizonte. This episode begins, in Nilson's version, the trajectory that led to the forced removal of the group of Guarani Mbya and Tupinikim to the Guarani Farm, and reiterates the practices of interception, control and repression of Guarani territorial movements, ${ }^{14}$ which had been used regularly by the Indigenous Protection Service in areas of recent colonization, as in the case of Pancas (ES), mentioned above. The fact that they were stopped by the police indicates the prejudice against the indigenous presence in urban space, and how they were persecuted as suspects ${ }^{15}$ violating their freedom of movement and removing the group to the National Indigenous Foundation headquarters in Minas Gerais.

13 The Guarani world-territory (ywy rupa) encompasses "the paths taken, the places occupied by the ancestors, the areas dreamed of, the temporarily unoccupied spaces, the places to still be appropriated" (Darella, 2004: 80) and ranges from Argentina and Uruguay, to Brazil's South and Southeast, until Pará, with the ocean its sole limit.

14 The circulation in cities, to sell crafts, combines efforts to earn money with relations of reciprocity in economic and social practices of indigenous collectives (Pissolato, 2016).

15 Vagrancy was considered at the time a misdemeanor by art. 59 of the Brazilian Criminal Code of 1942 . Vagrancy had been considered a crime since colonial times to provide a mechanism for state control over individual freedom and the occupation of time in a productive manner, related to the rise of free labor, the end of slavery and the formation of a reserve army for the emergent capitalism (Ribeiro, 200o). It triggers the arbitrary framing of a type of suspect, the legitimation of prejudice and the ethnic racial persecution (Goettert, 2006). Vagrancy was only decriminalized in 2012. 


\section{Refusal and removal}

The last narrative cited was presented in August 2013, at a public hearing of the Memory and Truth Comission of Espírito Santo, in the presence of Maria Rita Kehl, coordinator of the Peasants and Indigenous Working Group of the National Truth Commission. At the event, the testimony of Guarani Mbya and Tupinikim elders about their forced removal and imprisonment at the Guarani Farm caused surprise and discomfort among the public, which was composed mostly of urban victims of regime violence, who were still unfamiliar with the Indians experience, in a complacent ignorance of the events that reiterated the fable that "there were no Indians in Espirito Santo".

In a secluded location, Maria Rita Kehl heard the account of Guarani elder Marilza Carvalho Keretxu Endy about what happened at the AJMB headquarters, in Belo Horizonte, where the group was received by Captain Pinheiro, as he was known among the Indians. He had invited the Indians to go by plane to Brasilia, where he said FUNAI administrators would take measures concerning their lands in Espírito Santo. ${ }^{16}$ As she told of the group's refusal of Capitão Pinheiro's invitation, the Guarani leader was categorical about attributing a genocidal function to this means of transport under the regime. This fact was widely corroborated by the press and by the Figueiredo Report, ${ }^{17}$ which resurrected "countless ghosts, including hunts for humans, with machineguns and dynamite thrown from airplanes, deliberate smallpox contamination of isolated peoples and donations of sugar mixed with strychnine" (Santo Martins, 2015).

The active resistance of Guarani leaders and their refusal of the invitations and proposals sent by state agents was reiterated on several occasions, exhibiting their determination to remain on and protect their land on the north coast of Espírito Santo. The Guarani Mbya consider the areas of Atlantic Forest by the sea to be "elected places" (tekoa pora), which carry mythical and historical meaning, and where the original creations that were not destroyed by the flood are preserved, as well as signs (geographical formations, rocks, ruins) of the previous occupation by their ancestors, and the supporting elements of an imperfect and unstable earthly world (yvy vai). Therefore, they understand that for this world to exist, and for them to exist as Mbya in this world, that their access to these seaside forests (ka'aguy) must be guaranteed and they must be preserved (Ciccarone, 2011: 142).

- The guys were saying that they were Indians (...)

- What are they doing here?

- We are looking for our lands.

- But it was [during] the military regime, and the governor refused to meet them

(Rogério Medeiros, 1998).

The testimony of journalist Rogério Medeiros was not an isolated fact. The military regime continued to monitor, watch and punish Indians who denounced and clashed with the national land settlement program. The Tupinikim were classified as dead Indians, declared extinct by the SPI and the local researchers' account of their existence was ignored. The Guarani were labeled as "foreigners" considering the transborder nature of their vast territory, they were destined to the place of the other without land or any rights.

The developmentalist delirium promoted by the ideology of the military regime, with its moral ethnocide, had no room for difference. The linear and immutable positivist history that promoted "order and progress" was "followed in military lockstep in single line" (Rolnik, 1989: 191), as in the shocking scenes

16 Maria Rita Kehl received documentation about the forced removals and reclusion of the Guarani and Tupinikim at the Guarani Farm. But the Relatório Final da Comissão Nacional da Verdade, V. II, texto 5 - Violações de direitos humanos dos Povos Indígenas (dezembro 2014) [Final Report of CNV, V. II, text 5 - Violations of Indigenous Peoples human rights (December 2014)] has only a short mention of them (p. 245).

17 The Figueiredo Report, which was found in 2013 at the Museum of Indian (RJ), by researcher Marcelo Zelic, has over 7 thousand pages written by prosecutor Jader Figueiredo Correia. It is the most important document produced by the Brazilian government during the dictatorship to investigate the complaints of crimes committed against indigenous peoples. A first reading did not find relevant data for this study. 
of the parade of the first class of the Indigenous Rural Guard (GRIN), at their graduation ceremony in Belo Horizonte in 1970, which celebrated torture as a disciplinary practice in the capture of Indians by Indians themselves. $^{18}$

In 1972, at the UN Conference on the Human Environment, in Stockholm, Sweden, the Brazilian government delegates invited polluting industries to establish themselves in the country. While international observers focused on the devastation of the Amazon, the military regime was impunely assaulting and slaughtering peasants, quilombolas and indigenous groups. In times of an exacerbated appetite for land (Santos et al., 1994), the confrontation intensified against indigenous peoples. They were expelled from their territories that were expropriated, and transformed through economic and technocratic assessments, so the lands would acquire new social shape and thrive in the growing market of illegally seized and subdivided lands.

The accounts of the Guarani Mbya and Tupinikim who were imprisoned at the Guarani Farm concentrated on the most repressive period of the military regime, when Espírito Santo, governed by engineer Arthur Gerhart dos Santos (1971-1975), felt as if it was at the center of the world. For the new governor, the social and environmental losses represented "inevitable costs", considering the incomparable advantages of progress. ${ }^{19}$ The great sprint towards the modernization and integration of Espírito Santo came from eucalyptus, an exotic product, like coffee, confirming the state's "vocation" to produce and export raw materials.

Supported by a Forest Code (BRASIL, 1965) that assured tax incentives and exemptions, the reforestation company Aracruz Florestal (which later became the multinational company Aracruz Celulose) had the support of development agencies and governments, and received tremendous state and federal funding to produce a monoculture of eucalyptus in the state. The hegemonic narrative that "there were no Indians in Espirito Santo" became more powerful by transforming indigenous lands into a "demographic void", which were technically defined as an "extensive region of unoccupied and economically inexpressive lands". ${ }^{20}$

With the complicity of governments and the hiring of armed gangs, the company expropriated and devastated indigenous lands on the coast of the municipality of Aracruz (ES), ${ }^{21}$ using forgery of land deeds and violence against local populations (Calazans, M. (coord.), 2002; Gomes, H .\& Overbeek,W. (Orgs.), 2011). As the terror spread, the Tupinikim were coerced to abandon their villages, and scattered through the region, settling in the pockets of poverty of urban slums, while the traces of indigenous presence in the territory were erased. ${ }^{22}$ Despite being cornered, some Tupinikim families refused to abandon the village of Caieiras Velhas ${ }^{23}$ from where, amid rising tensions, the Guarani group temporarily left for Guarapari to sell crafts. From Guarapari, and on their frequent wanderings, they continued to accompany the events in the Aracruz indigenous lands.

\footnotetext{
18 This is a reference to the film Arara, directed by Jesco von Puttkamer, about the graduation ceremony of the first class of the Rural Indigenous Guard (GRIN) in 1970. The film was found at the Museum of the Indian (RJ), in 2012, by Marcelo Zelic, vice-president of the group Torture Never Again and coordinator of the project Memory Warehouse.

19 Arthur Gerhart dos Santos would later become a director of Aracruz Celulose.

20 Technical report produced by the consulting company ECOTEC, whose co-owner, Antonio dias Leite was one of the mentors of the Forest Code (DALCOMUNI, 1990: 186).

21 In 1967 the state government handed over to Aracruz Florestal the 10 thousand hectares explored by COFAVI, amplifying to 30 thousand hectares the size of indigenous lands dispossessed as if they were vacant lands and negotiated for "the symbolic amount of eight tenths of a hundredth of a cruzeiro per square meter" (Guimarães, 1982: 143).

22 Thirty-seven of the 40 Tupinikim villages scattered over the 40 thousand hectares of indigenous territory were destroyed. Only Caieiras Velhas and Pau Brasil remained, each with 25 hectares. The village of Comboios was preserved because it was in a restinga (a coastal forest). (...) Over the ruins of the Tupinikim village Macacos, the first pulp factory was built and inaugurated in 1978 by General Ernesto Geisel ( Gomes, H .\& Overbeek,W. (Orgs.), 2011: 6o).

23 A Parliamentary Investigative Commission (CPI) was established in 2002 by the Legislative Assembly of Espírito Santo to investigate frauds and socioenvironmental crimes during the establishment of Aracruz Cellulose. The work of the CPI was suspended in the next year, by a decision of Brazil's Supreme Court.
} 
We were working and explaining the history. Then, the people, the authorities, said to be patient: 'In another year, maybe three, it's possible that we'll find a piece of land for you'. The elders told us that this was truly an indigenous area. They said that there were Guarani here many years ago as well. The area here was a Tupinikim indigenous land and there was also other Indians, at that time there was the Tupinambá (João Carvalho, Kwaray Mymby, 1998).

The Tupinikim and Guarani organized to demand from FUNAI in Brasilia their rights to the lands that were invaded and destroyed by the multinational company, and held the indigenist agency responsible for enhancing the terror in the region. This might have been the trigger for the state agents to evacuate the indigenous area and try to transfer the Guarani group to villages in other states. But they met a firm refusal of the indigenous who were determined to assure their rights over the lands in the northern coast of Espírito Santo.

In March 1973, chief Paulo Benites Vera mirim Piriria, son of the shaman Tatatxi, went to the press to seek a hearing with the governor and claim the concession of an area close to the village of Caieiras Velhas that was recognized as an ancient site of occupation of his people. The Guarani group was getting public visibility in the state with media coverage of the events. In addition to the indigenous rights over the lands, the chief claimed documents existed that proved the legitimacy of his claims (A Gazeta, Mar. 17, 1973: 7).24 The press published the position of the agents of the military regime, who promised to find "an" area for the group and especially "any other solution, providing that it would be favorable to the Indians' claims, considering the government interest in the matter". (A Gazeta, Mar. 21, 1973).

In this new farce, employees of the Social Adjustment Center of the state Secretariat of Labor and Social Promotion monitored the group, claiming they did not have the resources to assist the Indians who "wandered in search of shelter" (Ministério do Interior, Aug. 13, 1973). At the same time, the state government declared that they were aiding the group of Guarani in Guarapari - who were living in a dramatic situation of hunger, sickness, destitution and harassment - providing them with clothing, food and medical, dental and sanitary assistance, "from the moment they arrived in the state".

The discriminatory discourse that referred to the Guarani Mbya as "foreigners, vagrants and nomads" still echoes, as a device for denial and violation of their rights over the lands which they affirm belong to them. The indigenous people challenge the state assaults that sought to control, submit and integrate a people who for centuries struggled to assure their autonomy and preserve their original territory (Melià, 1997).

With media coverage of attempts by the municipality of Guarapari to exploit the indigenous group as a touristic attraction in exchange for a land where they could settle, ${ }^{25}$ a new character of the military regime appeared, perpetuating the tutelary character of the indigenist policy. This served the state's developmentalist plan by administrating the forced removal of the Indians to the Guarani Farm (A Gazeta, Aug. 09 1973). The new deputy of the Ajudância Minas-Bahia (AJMB), João Geraldo Itatuitim Ruas, a Juruna Indian and former employee of the Indigenous Protection Service, like the majority of FUNAI's staff, following orders from Brasilia, gave priority to the removal of the Indians from Caieiras Velha. He was thus challenged to face the resistance of the Guarani, who were determined to remain on the Espírito Santo coast and return to the land of their ancestors.

In the internal communication from FUNAI previously mentioned (Ministério do Interior, Aug. 13 1973), deputy Ruas referred to the Guarani as "a group bamboozled by the Jesuit mystique that presents a series of psycho-religious complications (...) they are fanatical in relation to religious communitarian life”. He said that

\footnotetext{
24 The documents referred to a sesmaria (a colonial land grant) from 1760, marking 237,900 hectares of the original Tupiniquim territory in the north of Espírito Santo (VILLAS, 2011: 20).

25 During their stay in Guarapari, the state military police prohibited the Guarani from selling crafts and the Navy expelled the group from a seaside area, so they found shelter with evangelic churches (CICCARONE, 2011:305).
} 
to persuade them to accept the "transfer" to Minas Gerais, he enacted a religious ritual, and was convinced of the success of his farce. The performance proved to be a failure and an insult to the group guided by shaman Tatatxi Ywa Retee, which refused to move. The indignant resistance of the Guarani sharply emerges in the following account:

I did not know that Tatatxi went against her will; Itatuitim said to me that the farm was wonderful for them (...) The buses did not leave because Vera miri (Sérgio Carvalho dos Santos, Tatatxi's grandson) didn't arrive, he had been drinking (...)

Itatuitim said: Let's convince this boy, because the old woman is being very resistant.

I responded like this: Now we are leaving to the land of the Indians, you'll disappear.

Then he spit in my face. You white motherfuckers, you already took all the Indians' land (Rogério Medeiros, 1998).

The forced removal to the Indigenous Agricultural Colony Fazenda Guarani [The Guarani Farm] took place in August 1973, financed by the Espírito Santo state government (Ministério do Interior, Aug. 26 1973). The elder leader Marilza Carvalho, Keretxu Endy, recalled with irony the extensive efforts and resources engaged to expel the Guarani from the state. "The police, the army put them in the bus" (2013), while the press turned the violent action into a celebration of the indigenous people finding their "Promised Land". This was a manipulated characterization of their arrival at the Indigenous Agricultural Colony in the municipality of Carmésia (MG) (Jornal do Brasil, Aug. 19 1973), as part of their search for a "Land without Wickedness" - a cosmological category substantialized by the Guarani in their territorial mobility. ${ }^{26}$

The persecution by the military regime spread through the state, to suppress all evidence of indigenous presence, to guarantee the lands would be vacant and issued to agroindustry. Maria da Silva was taken by force from her home, in Vitória, by military police and led to a police station. There she waited together with her family group - led by chief Tupinikim from the Caieiras Velhas village, Benedito Joaquim Silva, and his wife, Almerinda Pinto Joaquim, who had been removed by force from their lands - for the arrival of buses "full of Guarani" (2013), that would transport them to the Guarani Farm.

At seven a.m., they came to my house; I was three months pregnant with my older son, Tatu, the police knocked on my door. It's the federal police.

- But I did nothing! I was scared.

- No, it's because you are Indian; you have to go to the Guarani Farm.

(Maria da Silva, 2013).

Maria worked as a housekeeper in the city, like many Tupinikim women expelled from their lands on the north coast of the state. She was married with a white man, yet "I knew I was daughter of Indians". However, her recognition as Tupinikim was a punitive attribution, when she was found and arrested.

The memory of the event and the recollections of the interactions with the state agents marked the production of personhood and kinship, with the attribution of names and nicknames. She came to be known as Maria Tupinikim and her older son as Itatuitim, "in homage" of the FUNAI deputy who, in turn, was identified by the nickname Tatuitino. These nominal bonds create associations that include the nickname (Viegas de Matos, 2008: 77) acquired by Maria's son, who the Tupinikim refer to as Tatu [Armadillo], in a symbolic reference to a telluric condition that illustrated the indigenous memories of the experience of reclusion.

26 The search for the Land without Wickedness (yvy = earth and marae' $y$ = without end, imperishable) has a prominent place in Guarani ethnology. Its multifactorial comprehension has a strong presence in works from the 1980s, with the mobilizations for regulation of land rights. There was a questioning of its ideologization, from the perspective of an earthly place with better living conditions, free from suffering and deprivation, during their territorial displacements. It was presented as an imperishable place that can be reached in life by crossing the "great water" that separates the earthly world from the eternal home. 


\section{The imprisonment hole}

The Guarani Farm began its operations as an Indigenous Agricultural Colony in 1972, after the closure of the Krenak Reformatory that was under the command of Captain Pinheiro from 1969 to 1972 . In a combined action between the state military police and the Indigenous Rural Guard (GRIN), which was a Krenak group that had been forcibly removed from their territory that was invaded by the Forestry Police and by farmers ${ }^{27}$ and confined to the Reformatory, which was established in 1969, at the Indigenous Post Guido Marlière, in Resplendor (MG). Together with Indians from other regions of the country detained at the institution to "assure their protection and reeducation", the Krenak were taken in 1972 to the Guarani Farm, in Carmésia (MG), where FUNAI planned to continue the recovery and forced integration plan by means of community development projects and the training of community leaders.

Located in an area of 120 "alqueires", the Guarani Farm - a former torture facility for political prisoners and a counterguerrilla training center of the Minas Gerais state military police - was ceded to FUNAI in exchange for the lands of the Krenak, in Resplendor, despite the fact that the in 1971 the Krenak had won a reintegration lawsuit for 4 thousand hectares. The exchange arranged by Captain Pinheiro with the federal and state governments, as celebrated by the press, guaranteed the colonization of indigenous lands and the emission of propriety titles to the tenants (Estado de Minas, Jun. 24 1971).

Most studies and news stories focus on the Krenak Reformatory, with rare attention given to the Guarani Farm. Studies by Soares (1992) and Matos (1996) draw on indigenous accounts about the Reformatory. Soares focused on the land conflicts that triggered arrest and imprisonment, denouncing the violence practiced by the militias, while Matos followed the trajectories of interethnic relations of the Krenak with settlers and indigenist agents. Caixeta de Queiroz (1999) examined the disciplinary character of the institution, as a materialization of the colonial policy of physical and symbolic violence perpetrated against the Krenak, practicing the culture of terror as a strategy of domination and control. Corrêa (2003; 2003) highlights the confidential character of the state agents' reports that deny charges of human rights abuses, and news reports. Reviewing the trajectory of the Indigenous Protection Service in the actions of recovery and reeducation of "criminal" and "unadjusted" Indians and in providing assistance and control of those considered "normal" (2003: 174), the author reveals the continuity of the existence of reformatories and their role in supporting the tutelary policy of the state.

The few and brief references to the Guarani Farm found in these studies are from a dissertation by Matos (1996), which focuses on the importance of the "demographic void" strategy in the appropriation of Krenak lands, highlighting the indigenous narratives about their violent removal to the Guarani Farm. Corrêa (2003) refers to the Guarani Farm as he questions the exclusive approach of the institution and the Reformatory as a prison system.

- Why did they bring you here? - Other Indians who were imprisoned asked (...). There were guards, 30, 40 Xavante, Karajá, Krenak Indians imprisoned, more than 100 people. (Marilza Carvalho, Keretxu Endy, 2013).

In August 1973 some 120 Indians from different peoples were detained at the Guarani Farm whose lands were occupied by non-Indian tenants and squatters. The groups removed from their lands in Espírito Santo were composed of 7 Guarani families, with 46 persons, and a Tupinikim family, with ten people, according to an internal FUNAI correspondence, in which deputy J. G. Itatuitim Ruas expressed his intention to remove to the institution another contingent of 22 Tupinikim. ${ }^{28}$

\footnotetext{
27 The Krenak fought against the colonization of their lands, returning to the area from where they were repeatedly expelled (Soares,1992; Matos, 1996). 28 MINISTÉRIO DO INTERIOR. FUNAI. Sep. 12 1973. The document written and signed by J. G. Itatuitim Ruas, makes an explicit reference to the Tupiniquim, and the new unsuccessful attempt to remove another 22 people.
} 
During the trip, and at the arrival to the Indigenous Agricultural Colony, the Indians received false promises about the abundance of the location: the supposedly farmable lands of the Guarani Farm were arid pastures, not suitable to planting. The few forests had little fish and game, there was a lack of raw material for crafts.

It was dawn when we arrived and I came smiling to talk to her: Oh, Tatatki, what a good land - She stared at me with a severe look, didn't return my smile, then Aurora (Tatatxi's daughter) said that she had dreamt that that would be a place of disgrace for the Guarani (...). I went there several times: she was always very sad, very sad.

(Rogério Medeiros, journalist, 1998)

The memory of the facial expressions of Tatatxi is a powerful image, evoked in the narratives of the whites about the shamanic leader. In those dramatic times, it manifest the intense experience of pain from being in a dark place, without joy, the sudden interruption and limitation of their freedom of movement and the end to their seaside walks, which are conditions vital to their existence. In the premonitions of the shamanic dreams, the announcements of death, conjugated in the oneiric space/time of visions of the future the memory of conflicts they had experienced together with the Krenak, in Resplendor (MG), when the migratory group had passed through the location in the 1960s. The memories of the violent dispossession from indigenous lands, which were subdivided into lots, and the tension, aggression and forced confinement of the Krenak, fed Tatatxi's dire premonitions.

There at the Guarani Farm, my nephew went hunting in the woods and stepped on an armadillo's tail. He walked further and stepped on a rattlesnake; there are many rattlesnakes. Then, he went close to the armadillos' hole and stepped there. Ten days went by (...) the doctor said: You are still alive? Still alive? - And he said he was fine. Twenty-four hours later the doctor came, gave him an injection, and that was it, he dropped dead. That's how my nephew Sérgio died.

(Paulo Benites, Vera mirim Piriria, 1998)

Outraged by the whites' deceits, Sérgio Carvalho dos Santos, Vera Guyra, Tatatxi's grandson who had spit in a journalist's face when embarking on the bus that took the group to the Guarani Farm, would be the first fatal victim of the imprisonment in a land inhabited with insidious deadly elements, that were manifest in a deadly attack by a poisonous snake and in a fall into the dark space of an armadillo hole. Snakebites were common, afflicting humans - like Aurora and Jonas, the mother and brother of the late Sérgio - and nonhumans, like cows, oxen and dogs. The repeated deaths associated to medical assistance were expressed in other narratives of the same Guarani groups, which told of aggressive and neglectful attitudes suffered mainly in hospitals in the interior, from where "it's easier to leave dead than alive" (Aurora Carvalho, Keretxu Miri, 1998).

The indigenous accounts of the imprisonment at the Guarani Farm evoke traumatic memories; they are fragmented, marked by gaps and forgotten elements; while they express tacit suffering, marks of coercion as violent as physical torture. The register of these accounts became a dialogical experience that overflowed with specific non-signifiable intensities (Favret-Saada, 2005). As I wrote this article, I continued to experience a sense of the profound inadequacy of the common analytical categories, as I had felt since my fieldwork. And though I have still not been able to address this conceptual gap as I had hoped, I knew that I at least could express the absence of registers of these experiences and insist on the right to recall them.

The Guarani narratives reiterate the deceit of the false promise that they would be given good land, yet were instead confined to a dangerous place unsuited to their way of life. In a space enclosed between hills, under the control of white men - military police, FUNAI employees and squatters - the "confinement" was a suffocating experience described as like being inside a hole, with no vital signs of movement or opportunities, contrary to the freedom of their wanderings (oguata) as a mode of existing on the horizon of 
becoming. The memory of a suffocating experience in a place with no horizons emerges in the Tupinikim accounts about the Guarani Farm as a final destination and location of forced exile that brutally interrupted their life trajectory.

There were many guards there (...) they didn't let anyone leave. Everything was surrounded by hills, there was no view (...). So, there, oh dear, it's no place...! My grandmother (Tatatxi) said: This is no place for us to live, no! (Jonas Carvalho, Tupa Kwaray, 2013)

They said that it was Indian land; that there was no danger (...). There was nothing even to plant (...) it was cooler, hillier, there was no distant horizon, it seemed like being in a hole (...) There was no stream, nothing, there were settlers, squatters; military police took over the Guarani Farm (João Carvalho, Kwaray Mymby, 1998).

There was a bunch of houses, with a street in the middle, an avenue, houses on both sides. They were farmer's houses (...) Krenak, Pataxó, Maxacali also lived there (...) Here, now it is your place, where you are going to live - said Tatuitinho (Itatuitim Ruas) and other persons that we knew (...). Then, we went there for that reason, never to return. (Maria Tupinikim, 2013)

Fragments of memories repeat images of a desolate inhospitable land, torn by cracks, holes, tunnels, which the narrators had seen and walked over, boys at the time, confined with their families, who wandered in curiosity, hearing stories and exploring the underground places.

That tunnel, many holes underground. It is a rich land, there was a lot of malachite, many precious stones there; It still has (...) Some of the old white men said - this is where the Army did their target practice.

(Nilson Joaquim da Silva, 2013)

There were big rifle bullets with lead, powder, large bullets, some not fired (Pedro da Silva, Karai, 2013).

There was a, a tunnel there, people went inside. We watched too, we were small and curious. There were bullets, shrapnel. (Agostinho da Silva Oliveira, Kwaray, 2013)

There is a munitions depot, rifles, all stored there. There are arms stored (Jonas Carvalho, Tupa Kwaray, 2013).

In that dangerous land, of violence, deceit and torture, the name of Captain Pinheiro echoed relentlessly in the narratives of Krenak and Tupinikim women.

My father died of disgust, he wanted to die at Krenak. Capitão Pinheiro brought many prisoners from all over the country, it was a jail. They deceitfully took us to the Guarani Farm; they said that there was a lot of fish, game to hunt, that it was a good place, all that gibberish. My father-in-law was handcuffed, the old man, they took him. Captain Pinheiro drank cachaça, they said they would talk, they came close to cuff them. They chained the Indians in jail and beat them (..) We lived like dogs there (Dejamira de Souza, Krenak, 1981). ${ }^{29}$

The time of Captain Pinheiro was harsh. They said they were whipped(...) There was a solitary cell in a big house where Captain Pinheiro hanged people (Maria Tupinikim, 2013).

29 Narrative collected at the Guarani village Boa Esperança (ES), where the Krenak and Karajá that had joined the group at Guarani Farm were living. In: RELATÓRIOS DO CTI EM ARACRUZ POR LILIA VALLE. São Paulo: Centro de Trabalho Indigenista. - 1979 à 1984. 
In contrast to the accounts of the indigenous silenced in "confinement", the press released stories that emphasized the humanitarian contribution of the indigenous agent of the military regime, the Juruna J. G. Ituatuitim Ruas. The continuity of the image presented by the Indigenous Protection Service of a protectionist and tutelary nation-state that implemented a "great siege of peace" (Souza Lima, 1995) over indigenous peoples and their territories, was enhanced by the alliance with the press. Elevated to the heroic executor of the national project of integration and emancipation, Deputy Ruas claimed to be an Indian in the name of Indians: Above all, I am an Indian. My role is to help them to find and keep their freedom (...) I try to be an example as an Indian and encourage them (...): the Indian struggles and integrates or is swollen by civilization. (Revista Realidade, Dec. 1973; Revista Espírito Santo Agora, 1973).

Against the announced death, facing the misfortunes and strengthening themselves with daily prayers and songs, led by shamanic leader Tatatxi, guided by her guidance and dream revelations (Taussig,1993) Guarani leaders led actions of revolt and mobilization for the recovery of the lands on the northern coast of Espírito Santo.

My mother did not want to stay, she wanted to come here, we like it here, by the sea, and that's why we returned (Paulo Benites, Vera mirim Piriria, 1998).

An intense confidential correspondence from the indigenist agency was produced a few months after the group from Espírito Santo arrived at the Guarani Farm. Antônio Vicente, chief of the Indigenous Post, requested the intervention of the deputy of AJMB, considering the continuous dissatisfaction of the Guarani who complained about their extremely precarious state and that they are determined to leave (...) the Indians sleep on the ground, suffering from cold and lack of food (Ministério do Interior, Oct. 31 1973). The most aggressive and rude are the Guarany, who are always dissatisfied with everything and everyone" (Ministério do Interior, Jan. 28. 1974).

With the lack of funding for community development projects and to train community leaders, the purportedly exemplary integrationist "reeducation" laboratory for the Indians quickly proved to be a place of repressive practices, in conditions of poverty and suffering; a segregationist and punitive penal facility. The complaints and rebellions of the Indians were punished by charges of contempt for authority, vagrancy and drunkenness, and the accused were placed in solitary confinement, for as long as the arbitrary chief of the Indigenous Post wanted, and depending on the ability of the Indians to pressure for the prisoners' release.

While the Guarani narratives focus on the motives for and time of detention, due to the total privation of freedom of movement, among the Tupinikim the emphasis was on the mobilization of prisoners to demand their freedom:

He was drunk and Vicente ordered him to be placed in a cell (...). Lots of Indians were jailed, they couldn't leave (...)

(Mario Carvalho, Vera Miri, 2013)

There was one that was never released. He was always there, I think he was from Amazonas, all the Xavantes were arrested, a Tucano Indian was arrested (...) Once, my uncle Mario got drunk, then he was put in jail, but wasn't beaten. (Jonas Carvalho, Tupa Kwaray, 2013)

A jail that is in the ground, underneath (...) it was the Coronel's (Captain Pinheiro) who locked people up (...) I had a fight with Vicente (the Chief of the Post) he threw me in there, with other people, threw me in there (...) The Guarani relatives, my relatives, got together and went to fight there, and they let me go (Nilson Joaquim da Silva, 2013). 
In December 1973, the approval of the Indian Statute (Law 6001/1973) by defining "indigenous land" as a juridical category - although the legal structure remained adherent to the previous indigenous policy set the foundation for the indigenous people's struggles for land rights (Souza Lima, 2015). The military regime was pressured into passing the bill by international sponsors of the "Brazilian miracle" (including the World Bank), which in turn were embarrassed by organizations who fought for human and indigenous rights (Souza Lima, 2015: 439).

In this context, despite the scarce visibility of regions of Brazil not within the international focus on the Amazon, controlling the release of news about the violent practices at the Guarani Farm became an urgent task of the indigenous agency, which contacted the press to release declarations from the AJBM deputy about the protection of the Indians detained at the institution, defending the emergency and temporary character of the action. While he announced that the reclusion was close to an end, and remained silent about the fate of the "recovered" Indians (O Globo, Dec. 6 1973; Mota; Waldemar, 1973), deputy Ruas also repressed escape attempts, prohibited the indigenous from leaving the facility and blocked the arrival of a group of Guarani Mbya from São Paulo who came to support their arrested kin (Ministério do Interior, 11 abr. 1974).

The announcements of freedom resounded like shots from machine guns at the old counterguerrilla training center.

\section{Citizens useful to slavery}

The Guarani Farm wasn't only for Guarani, it was FUNAI's, and there was slave work as well (...). It was a place of slavery. There are houses there from the time of slavery. There was one with chains for binding a leg, the foot.

(Jonas Carvalho, Tupa Kwaray, 2013)

In addition to the weapons, ammo, stray bullets, in the layers of violence sedimented in the lands of the Guarani Farm, the remnants of iron chains echoed the time of captivity, when slave labor became present again.

In the beginning of 1974, an internal FUNAI correspondence indicated that 88 Indians classified as "acculturated" who were detained at the Guarani Farm were found: naked, hungry and submitted to slave labor at nearby farms, working with crops and cattle (Ministério do Interior, Apr. 20 1974).

I had to work for the farmer, it happened. It was in exchange for something, an exchange for something that I wasn't paid. (FUNAI) didn't care anymore about supplies, the chief of the post disappeared (Nilson Joaquim da Silva, 2013).

The FUNAI deputy at AJMB Minas justified the slavery as a way for Indians to become useful citizens.

The Indian cannot live only receiving, like an inactive element. It is necessary to teach him to produce, to show that if the white produces and develops to survive, he can do the same (João Geraldo Itatuitim Ruas, Jornal do Brasil, Mar. 03 1974).

While in the internal mailing of the indigenist organ, the state agents seemed to be committed to assuring the survival of the prisoners, through donations, and the buying and selling cattle with local farmers, the indigenous narratives stressed the collusion of the state agents with the slavery. In the context of tensions and threats from the settlers who occupied and invaded the lands of the Guarani Farm, the false promises of free lands were renewed by disguising the slave work on the plantations in eventual exchange of food for the Indians to stay alive. 
I also worked a lot there and didn't get paid. There was no stream, nothing (...) There were small peccary and pacas in the woods, there was little forest. It was grasslands and hills (...) We couldn't even walk in the woods, we couldn't even hunt (...) there was a farmer, there in the area, the Guarani Farm, very angry (...) he promised he would kill Indians (...) The farmer took his cattle there, the cattle came in and destroyed everything. FUNAI let them.

(João Carvalho, Kwaray Mymby, 1998)

(FUNAI agents) told us: We have a farm in Valadares; you are going to plant, to bring back for yourselves - Later, they said they would give us as well, for every family who worked there, and they gave nothing (...) We drove (the cattle), the cattle ran and fell into a hole (...) And they said: You can kill it for you to eat - So we ate it (...) We even worked on a eucalyptus plantation (...) Far from Carmésia, about two hours (Jonas Carvalho, Tupa Kwaray, 2013).

(FUNAI) sent trucks full of Indians to lands near Valadares, to crops of beans, corn, rice. Then took them back to the Guarani Farm. Every day they sent two full trucks. Working in exchange for food. If you didn't work, you didn't receive food. Little food and no money. (Marilza Carvalho, Keretxu Endy, 2013).

In 1981, the anthropologist Lilia Valle recorded a narrative by Aurora Carvalho, Keretxu miri, daughter of the shamanic leader, about an emblematic episode that took place at the Guarani Farm. There was a confrontation of Guarani women and National Indian Foundation agents who were in collusion with the land invasion at the Agricultural Colony, in a persistent violation of its policies and false promises..$^{30}$

The cattle was there, but when it got in, it ate all the corn, cleared the land (...) I went to the Post, where the men were, the chief of the Indians, and I spoke with them: Oh, our leader, why are you our leader, you have to complain when something happens to us. He said: I will sell the calf so you can buy wire to fence your crop.

Well, if it's true, I'll wait.

So, he was lying; until now, we never got the wire (...). So, I asked my mom and, then, she said: 'Then we are going back to Caieiras Velhas again, where there are no cattle and we can work for us to earn at least a small plot of earth to farm. (Aurora Carvalho, Keretxu miri, 1998)

Guarani people used to say in their sacred utterances and daily teachings that the forests, with their living beings, were destined to them in the creation of the world, to protect them and they would reproduce on earth; while the fields, with its plain areas and creatures, like cattle, goats and horses, were reserved for the white people, whose numbers had grown so much and they began to covet and invade, with violence and lies, the indigenous lands, clearing forests and turning them into cattle pastures and city. Even if they are becoming scarce, small and scattered among white occupations, the areas of forest where they maintain and perfect their way of life, hunting, farming, guide the walks of the Guarani and their struggles for land to safeguard their territory.

\section{Alliances and Escapes}

In the authoritarian times of the policy to integrate Indians to as slave farmworkers and cow hands after expelling them from their lands that were given to settlers; the Guarani, Tupinikim and other imprisoned Indians launched a counter attack, with escape plans and denunciations of the living conditions on the Guarani Farm. The conviviality among Indians of different peoples, who had also been removed from their lands and isolated from their collectives in a scheme of domination and exploitation

30 The audiovisual recording of the narrative was made during a trip to Espírito Santo by anthropologist/filmmaker Andrea Tonacci in 1979, after the retaking of the area claimed by the group led by shaman Tatatxi Ywa Retee. 
inherited from the times of the Jesuit reductions, had multiple well-known effects such as alienation and tension. However, there were less explored effects: the preparation and emergence of leaders, agencyings of alliances, friendships and marriage. The times of reclusion shared at the Indigenous Agricultural Colony established networks of relations that escaped the control of state agents and the time-space limits imposed by the confinement. The alliances strengthened the daily resistance (Scott, 2000) like the pressure placed on employees and the monitoring of the guards so that they could escape their control. To contain the rebellions, FUNAI agents engaged the militias to detain prisoners and prevent escapes. They also tried strategies like monitoring cultural presentations at charity events held so the indigenous could earn some resources (Jornal do Brasil, Apr. 20, 1974).

At the Guarani Farm, a prisoner couldn't go any where and came from any place (...) They escaped and returned. My uncle João came and left. (...). They said: Here you will be safe. They returned to the Guarani Farm (Marilza Carvalho, Keretxu Endy, 2013).

They didn't let us, they said there was nothing left, no more places for Indians. But later we left, without an order, without asking for an order (João Carvalho, Kwaray Mymby, 2013).

We began to escape; we also worked, but couldn't leave (Joana Carvalho, Tatatxi, 1998).

If the efforts of regime agents' sought to help the fulfillment of the plan announced by the deputy to make the Indians useful citizens - mostly housekeepers and underpaid farmworkers (Ministério do Interior, Apr. 1974) - a reserve of slave labor to support development and progress, FUNAI's internal communications include numerous references to requests, mainly from the Guarani detainees, for resources to sell their crafts in the cities and at the facility entrances (Ministério do Interior, Jun 14 1974). It was essential to have the ability to travel between villages to be able to organize and engage people for a return to the village of Caieiras Velhas. In the movements between the north coast of Espírito Santo and the Indigenous Agricultural Colony, the alliance between Tupinikim and Guarani leaders fed an information network about the events on the indigenous lands in Aracruz and helped to denounce to the press the conditions of extreme poverty and aggressions from the settlers at the Guarani Farm (A Gazeta, Oct. 20, 1975).

After the failure to control the indigenous mobilizations, in order to block the return of the Guarani group to the north coast of Espírito Santo, the AJBM deputy prepared to send them to an area on the Bahian coast, but the group firmly refused, as they were determined to return to the place revealed in a dream to the shamanic leader and destined to them. In a new effort to preserve the humanitarian image of the FUNAI deputy, the press never presented the political agency of active resistance by the Indians, developing a mystical narrative about the nomadic life of the group (Espirito Santo Agora, Apr. 1975). The stereotypes nourished by the press acted as symbolic handcuffs, justifying their detention and the interests of the developmentalist state, which strengthened itself by denying the Guarani's cosmopolitics, and their forms of territoriality that weave networks of reciprocity and mobilize the search through Atlantic forest remnants for dreamed vital ancestral and therefore sacred spaces that configure their world-territory.

We went to the Guarani Farm in 1973 and stayed until 1978, but the people that went there never got used to staying there, because the walk of the Guarani was always by the sea as far as Pará, close to Marajó Island. This is the path of the ancestors (Antônio Carvalho, Vera Kwaray, 1998). 
Since 1975, the amount of internal FUNAI correspondence about the situation of complete abandonment of the facility was diminishing, amid a situation of intensifying tensions between Indians and settlers. The press did not give up controlling news about any denunciations and depoliticizing the Guarani determination to return to the coast, producing the image of a harmless and domesticated a group that had converted to Pentecostalism, once again misconceiving the category Land without Wickedness as their return to the coast because of the climate (Petrolli, Medeiros, Farman, 1976).

The arrival at the Guarani Farm of the Guarani Mbya group from São Paulo that had been barred entrance by the Juruna deputy, would strengthen the organization and engagement of the Indians guided by Tatatxi. In early 1977, they continued to denounce the alarming situation at the facility (Jornal do Brasil, 04 dez. 1977) and there were continuing escapes by small groups that in a series of steps returned to Caieiras Velha, where they found intense deforestation underway. The prompt denial by Governor Élcio Alvares (1975-1979), of a new claim to the area on the coast of the municipality of Aracruz would launch a trip by Guarani and Tupinikim leaders to Brasilia, to question the indigenous agency about the intention to remove the Tupinikim once again, with whom they had been articulating the struggle to retake their lands.

When we returned from the Guarani Farm, they were already starting to cut down the trees, the forest, with the tractor. We continued to fight and there was about eight tractors, bigger than this one, pulling chains to tear down the forest. One night, they knocked down an entire crop! This is what has happened. They were in a hurry, they tore it down. They destroyed all the animals living in the woods (João Carvalho, Kwaray Mymby, 1998).

The long and secret fate of the Tupinkim was broken in 1975, at a meeting of the Brazilian Society for the Progress of Science (SBPC) in Curitiba, where the AJMB deputy J. G. Itatuitim Ruas announced the "discovery" of the Tupinikim as remnant Indians. But over the years of silence about this people, their forests on the north coast of Espírito Santo were being frenetically devastated and transfigured into a broad eucalyptus monoculture, transforming the great diversity of life in the region into a vast desert.

We endured and when we came here, when we arrived here the woods were gone; it was canceled

(Nilson Joaquim da Silva, 2013).

In the second half of the twentieth century, in Espírito Santo, the military regime reproduced an updated version of Brazil's origin myth: the "conquest" of lands and "discovery" of original peoples. In neocolonial times, the policy was to convert the others into a subproduct of themselves, accompanied by a developmentalist assault in defense of the hegemonic narrative that "there were no Indians in Espírito Santo". This was nourished by presenting stereotypes of the Tupinikim as "remnants" of an "authentic" original identity and of the Guarani as "nomadic and foreign" Indians. These were force-images rooted in the persistent violations of their human and territorial rights.

The denouncements of the abuses and violence against the Indians committed at the Guarani Farm were released in the press (Jornal do Brasil, Dec. 03 1978), without the state assuming any responsibility. And the denouncements were brief enough to allow forgetting the traumatic memory of years of human rights violations, and to draw the attention of the press to the acts of resistance by the Tupinikim to the new attempts to remove them from their lands. Despite the denouncements, the Guarani Farm, according to Matos (1996: 86) continued to receive criminal Indians until 1986.

The events that followed the return of the Guarani and Tupinikim who had been detained at the Guarani Farm to the north coast of Espírito Santo are known to those who are familiar with the literature in the field (Silva, 2000; Calazans, M., 2002; Gomes \& Overbeek (Orgs.), 2011). Here, they are briefly evoked in the account of one Guarani leader, addressing the indigenous mobilization that demanded their lands in the late 1970s, still under the military regime. 
We gathered Guarani and Tupinikim, we united ourselves; we must unite the spirit of Tupinikim and the spirit of Guarani. All united so there is no fight, no war and then the land has to be given back for the Indian to feel happy. This is what happened. That is why we fight together, but we took many years to have a small piece of this forest, so we could feel happy (João Carvalho, Kwaray Mymby, 1998).

\section{Conclusion: memories in becoming}

Three thousand hectares of the Guarani Farm were approved as an Indigenous Land in 1991, inhabited by the Krenak and mostly by Pataxó who, during the military regime, had been forcibly removed to the facility, due to land conflicts near Porto Seguro (BA). The memory of the place with the same name lingers and has been transformed, domesticated by the territorial practices of the indigenous collectives, including the appropriation of the facilities of the prison colony for housing and food storage.

The relations forged in times of imprisonment have also been renewed and recreated in kinship networks, festivals, encounters of generations and leaders, in the wanderings and exchanges, such as those between the Krenak and Guarani, in their circulations through their territories, that traverse regional borders.

We stayed in Resplendor (MG) before we arrived here in Espirito Santo and there we met Sete Saloes. There, there are houses under the rocks to hide, many animals, good water that flows from the rocks. My grandmother (Tatatxi) said that Sete Salões was a place to be safe. If war came, we should hide with children at Sete Saloes. It is a place for the enchanted, you cannot see, it never dies (Marilza Carvalho, Keretxu Endy, 2013).

Narratives of resistance like those transcribed in this article continue to circulate, revising and strengthening the right to remember, which has been recognized too late for the indigenous people by the Brazilian state. The accounts flourish in fragments and powerful images, as in Maria Tupinikim's ${ }^{31}$ dreams and in the Guarani cosmography (Little, 2002:274), drawn by the elder Marilza, weaving the threads of heroic biographies of indigenous women, who domesticate territories of terror, as protagonists of another historiography, yet to be produced.

Received: September 17, 2017

Approved: March 04, 2018

Translation: Jeffrey Hoff

31 Maria Tupinikim requested the complete photographic collection from the time of imprisonment at the Guarani Farm from journalist and photographer Rogério Medeiros, some of which has been delivered to the Guarani Mbya and the Tupinikim of the villages in the municipality of Aracruz (ES). 


\section{References}

CAIXETA, C. Queiroz de. 1999. Punição e etnicidade: estudo de uma “Colônia Penal Indígena”. Master's dissertation, FAFICH, UFMG- Belo Horizonte.

CALAZANS, M. (coord.) 2002. Violação de direitos econômicos, sociais e culturais na nonocultura do eucalipto: a Aracruz Celulose e o Estado do Espírito Santo. Vitória: FASE.

CALHEIROS, O. 2015. "No tempo da guerra': algumas notas sobre as violações de direitos dos povos indígenas e os limites da justiça de transição no Brasil”. Revista Verdade, Memória e Justiça, (online), 9: 4.

CICCARONE, C. 2001. Drama e sensibilidade: Migração, Xamanismo e Mulheres Mbya Guarani. PhD Thesis. PPGCS, PUC- São Paulo.

.2011. "Um povo que caminha: notas sobre movimentações territoriais guarani em tempos históricos e neocoloniais". Dimensões, 26: 136-151.

CORRÊA, J. G. Silveira. 2003. "Política indigenista, tutela e deslocamento de populações: a trajetória histórica dos krenak sob a gestão do serviço de proteção aos índios". Arquivos do Museu Nacional, 61(2): 89-105.

. 2003. "A proteção que faltava: o reformatório agrícola indígena krenak e a administração estatal dos índios". Arquivos do Museu Nacional, 61(2): 129-146.

DALCOMUNI, S. Maria. 1990. A implantação da Aracruz Celulose no Espírito Santo principais interesses em jogo. Master's dissertation in agricultural development. UFRJ, ICHS - Rio de Janeiro: 186.

DARÉ, Raquel. 2010. A “crise" do café e a ideologia desenvolvimentista no Espírito Santo. Master's dissertation. UFES, PPGG- Vitória.

DARELLA, M. D. P. 2004. “Territorialidade e territorialização Guarani no litoral de Santa Catarina”. Tellus, $4(6): 79-110$.

DOSSIÊ Violações de Direitos os Povos Indígenas. 2017. Revista Aracé, Direitos Humanos em revista, 4(5).

FAVRET-SAADA, J. 2005. "Ser afetado". Cadernos de Campo, 13: 155-161.

GALEANO, E. 1999. De pernas pro ar. A escola do mundo ao avesso. Porto Alegre: L\&PM. English version from GALEANO, Eduardo. Upside Down: A Primer for the Looking-Glass World. Picador USA, New York, USA (1998).

GOETTERT, J. Dari. 2006. “Aos 'vadios', o trabalho: considerações em torno de representações sobre o trabalho e a vadiagem no Brasil". Formação (on line), 2(13): 109.

GOMES, H. \& OVERBEEK,W. (orgs.) .2011. Aracruz Credo. Vitória: Rede Alerta contra o Deserto Verde / Rede Brasil v. 40.

GUIMARÃES, E. M. 1982. "Sobre a situação de bens imóveis pertencentes ao patrimônio indígena no Estado do Espírito Santo". In: S. Coelho Santos (org.), O índio perante o direito. Florianópolis: UFSC. pp. 143-150.

LADEIRA, M. I. 2001. Espaço geográfico Guarani Mbya: significado, constituição e uso. PhD Thesis - Geography. USP, FFLCH- São Paulo.

. 2007 [1992]. O caminhar sob a luz: o território Mbya à beira do oceano. São Paulo: UNESP.

LIMA, E. Coffaci de; PACHECO, R. 2017. “Povos indígenas e justiça de transição: reflexões a partir do caso Xetá". ARACÊ - direitos humanos em Revista, 4(5): 219-241.

LITTLE, P. E. 2002. "Territórios sociais e povos tradicionais no Brasil: por uma antropologia da territorialidade". Série Antropologia, 322 :274.

MATOS, I. Missagia. 1996. Borum, Bugre, Kraí: constituição social da identidade e da memória étnica Krenak. Master's dissertation - sociology, UFMG - Belo Horizonte.

MOREIRA, V. Maria Losada. 200o. “Vazios demográficos ou territórios indígenas?” Dimensões, 11: 137-144

MELIÀ, B. 1997. El Paraguay Inventado. Asunción: CEPAG.

OLIVEIRA FILHO, J. Pacheco. 1999. Ensaios de antropologia histórica. Rio de Janeiro: Editora UFRJ: 9 
PACHECO, Renato. 1955. "Caieira Velha, onde os índios não andam despidos”. O Diário. Ano I, Vitória, Sep. 25.

PARAÍSO, M. Hilda Baqueiro. 1992. "Os Botocudos e sua trajetória histórica”. In: M. Carneiro da Cunha (org.). História dos índios no Brasil. São Paulo: Companhia das Letras. pp. 413-430.

PISSOLATO, E. 2016. "Trabalho, subsistência e dinheiro: modos criativos na economia mbya (Guarani) contemporânea”. Horizontes Antropológicos, 22(45): 105-125.

RIBEIRO, L. R. Pereira. 200o. “Vadiagem”. Âmbito jurídico I, n. o. Disponível em: <http:/|www.ambitojuridico.com.br/site/index.php?n_link=revista_artigos_>. Access in Nov. 162017.

ROLNIK, Suely. 1989. Cartografia sentimental. Transformações contemporâneas do desejo. São Paulo: Estação Liberdade.

RUSCHI, Augusto. 1976 [1954]. “Grupos antropológicos indígenas do E. E. Santo. Causas de seu desaparecimento. Dados sobre a população e a área de floresta para sua sobrevivência”. Boletim do Museu de Biologia. Serie Proteção à natureza, 18: 1-20.

SANTO MARTINS, F. do Espírito. 2015. "A justiça distributiva como práxis da Comissão Nacional da Verdade: uma possibilidade de reparação às sociedades indígenas no Brasil”. Revista Direitos Humanos e Democracia, 3(5): 4-28.

SANTOS, M.; SOUZA, M. A. A. de; SILVEIRA, M. L. (orgs.).1994. Território, globalização e fragmentação. São Paulo: HUCITEC.

SCOTT, J. C. 2000. Los dominados y el arte de la resistencia. Discursos ocultos. Mexico: Era Edições.

SILVA, S. J. da. 200o. Tempo e espaço entre os Tupiniquim. Master's dissertation. IFCH, UNICAMP - Campinas. SOARES, G. Chaves. 1992. Os Borum do Watu, os índios do Rio Doce. Contagem (MG): CEDEFES.

SOUZA LIMA, A. C. de. 2015. "Sobre tutela e participação: povos indígenas e formas de governo no Brasil, seculos XX/XXI”. Mana, Estudos de Antropologia Social, 21(2): 425-457.

TAUSSIG, M. 1993. Xamanismo, colonialismo e o homem selvagem: um estudo sobre terror e cura. Rio de Janeiro: Paz e Terra.

VALLE, Lilia. Relatórios Do CTI Em Aracruz. São Paulo: Centro de Trabalho Indigenista. - 1979 à 1984.

VIEGAS DE MATOS, S. 2008. "Pessoa e individuação: o poder dos nomes entre os Tupinambá de Olivença (Sul da Bahia, Brasil)" Etnográfica [online], 12(1): 71-94.

VILLAS, Fabio. 2011. "Tupiniquins e Guaranis: símbolos de resistência”. In: H. Gomes \& W. Overbeek (orgs.), Aracruz Credo. Vitória: Rede Alerta contra o Deserto Verde / Rede Brasil v. 40, pp. 17-30.

VIVEIROS DE CASTRO, E. B. 2017. "Sobre a noção de etnocídio, com especial atenção ao caso brasileiro" $\langle$ https://www.academia.edu/25782893/Sobre_a_noção_de_etnoc\%C3\%〉. Access in Nov. 142017.

\section{Official papers and press stories}

BALZA, G. Comissão da Verdade apura mortes de índios que podem quintuplicar vítimas da ditadura. UOL Notícias. https://noticias.uol.com.br/politica/ultimas-noticias/2012/11/12/comissao-da-verdade-apuramortes-de-indios-que-podem-quintuplicar-vitimas-da-ditadura.htm. Access in Nov. 2017.

BRASIL. Federal Law no 4.771 de 15/o9/1965. Institui o novo Código Florestal. Brasília, DF, nov. 1965.

CAMPOS, A. "Denúncias apontam o Reformatório Agrícola Krenak, em Minas Gerais, como centro de tortura de índios durante regime militar". Brasil de Fato, Oct. og 2012.

CNV. Resolution n. 5 Nov. 162012 D.U.O.

COMISSÃO ESTADUAL DE DIREITO À VERDADE, À MEMÓRIA E À JUSTIÇA DO AMAZONAS. A ditadura militar e o genocídio do povo Waimiri-Atroari. 2015.

CONCESSÃO de terras para índios guaranis depende dos arquivos. A Gazeta, Vitória, Mar. 17 1973. p.6.

É A BUROCRACIA, Piririá. A Gazeta, Vitória, Mar. 211973. 
CTI. Violações aos direitos humanos e territoriais dos Guarani no Oeste do Paraná: subsídios para a Comissão

Nacional da Verdade. Relatório do Centro de Trabalho Indigenista. 2014.

FUNAI decidiu: não expulsar colonos. Jornal Estado de Minas, Belo Horizonte, Jun. 241971.

GUARANIS chegam à terra prometida. Jornal do Brasil, Aug. 19 1973. $1^{\circ} \mathrm{Cad}$.

GUARANIS dão festa em Valadares. Jornal do Brasil, Apr. 201974.

GUARANIS abandonam reserva para fugir de vida sub-humana. A Gazeta, Vitória, Oct. 20 1975. p.5.

ÍNDIO quer terras em Aracruz. A Gazeta, Vitória, Mar. 17 1973, p.7.

ÍNDIO vem de Carmésia fazer denúncia. Jornal do Brasil, Dec. 41977.

ÍNDIOS levados de Guarapari a Minas. A Gazeta, Vitória, Aug. 09 1973. p.4.

ÍNDIOS recuperados voltam às tribos. Jornal O Globo, Rio de Janeiro, Dec. 06 1973. p.10.

ÍNDIOS em busca da terra. Espírito Santo Agora, Vitória, n. 17, Apr. 1975.

ITATUITIM e os índios. In: Revista Espírito Santo Agora, Vitória, n. 10, 1973

MINISTÉRIO DO INTERIOR. FUNAI. Ajudância Minas-Bahia, de Aug. 04-13 1973. Mailing to the regional deputy to the DGO, on the report of Prof. José de Aguiar, state secretary of Labor and Social Promotion of Espírito Santo, Aug. 1973.

. FUNAI. Ajudância Minas-Bahia. Sedoc, 247. Relação das despesas realizadas com os índios Guaranis. Belo

Horizonte, Aug. 261973.

. FUNAI. Encaminha relatório de remoção dos índios Guaranis no estado do Espírito Santo (Guarapari). Ofício

n. 373/AJMB/73. Belo Horizonte/Brasília, 12 set. 1973.

. FUNAI. Relatório de Antônio Vicente Segundo, chefe do posto indígena Crenack (Fazenda Guarany) ao Sr. João

Geraldo Itatuitim Ruas - chefe da AJMB/Gov. Valadares. Brasília, Oct. 311973 (Fl307/Ft.00728/00729).

. FUNAI. Lembrete. Do chefe do PI Crenak/Fazenda Guarany, ao Sr. João Geraldo Itatuitim Ruas - chefe da

AJMB/Gov. Valadares. Brasília, Jan. 28 jan. 1974 (Fl 307/Ft.0848).

. FUNAI. Apresentação. Oficio n. 054/74. Brasilia, 11 abr. 1974 (Fl307/ft 01144)

. FUNAI. Ajudância Minas-Bahia. Colônia Agrícola Indígena Guarany. Relatório sobre a situação da

Colônia. Apr. 1974 (ft307/fl839)

. FUNAI. Apresentação de índios. Oficio n. 077/74. Brasília, Mai. 251974.

. FUNAI. Apresentação. Oficio n. 084/74. Brasília, Jun. 141974.

MOTA, G. e WALDEMAR, S. "Nostalgia do mar tirará os guarani de Minas”. Jornal do Brasil, Dec. 091973.

O ÍNDIO chegou ao poder. "O super-cacique da FUNAI pagará sua promessa?” In: Revista Realidade, ano VIII,

n. 93, Dec. 1973.

PASSOS, N. "Houve extermínio sistemático de aldeias indígenas na ditadura”. Carta Maior, Aug 022012.

PETROLLI, C.; MEDEIROS, R.; FAERMAN, M. "Os últimos tupiniquins (a ilusão da terra sem males)". $O$

Estado de São Paulo, São Paulo, Mar. 301976.

PRESIDENTE da FUNAI confirma violências contra nossos índios. Jornal do Brasil, Dec. 031978.

POVOS Indígenas e Ditadura Militar: subsídios à Comissão Nacional da Verdade 1946-1988. Partial Report. 01

Nov. 30 2012. Available in: https://idejust.files.wordpress.com/2012/12/povos-indc3adgenas-e-ditadura-

militar-relatc3b3rio-parcial-30_11_2012.pdf. Access in Nov 2017.

\section{Celeste Ciccarone}

Federal University at Espírito Santo (UFES),

Center of Humanities and Natural Sciences (CCHN), Department of Social Sciences

https://orcid.org/oooo-0002-1133-6285

E-mail: celeste.ciccarone@gmail.com 